\title{
VACCINATION AGAINST 77 CAPSULAR TYPES OF KLEBSIELLA AEROGENES WITH POLYVALENT KLEBSIELLA VACCINES
}

\author{
R. J. Jones AND E. A. RoE \\ MRC Vaccine Research Laboratories, Clinical Research Block, Medical School, \\ Birmingham B15 2TJ
}

\begin{abstract}
SUmmaRY. A method is described for producing monovalent and polyvalent vaccines from culture filtrates of Klebsiella aerogenes. With a single injection, each monovalent vaccine protected mice against lethal intraperitoneal challenge by more than 30 capsular types; and polyvalent vaccines containing 2-12 monovalent components protected against 46-61 of the 77 capsular types of $K$. aerogenes. One vaccine with 12 components, administered in two doses, induced full protection against 71 types and protected half of the mice challenged with the other six types.
\end{abstract}

\section{INTRODUCTION}

The importance of Klebsiella aerogenes as a major opportunistic pathogen is well documented (Steinhauer et al., 1966; Rennie and Duncan, 1974; Young, 1982; Bryan, Reynolds and Brenner, 1983). Specific associations include debilitated patients (Foster and Bragg, 1962; McHenry and Hawk, 1974; McCabe et al., 1977; Young et al., 1977; Wardle, 1979; Ziegler et al., 1982), cancer (Umsawasdi et al., 1973), renal transplants (Montgomerie et al., 1970), neurosurgery (Price and Sleigh, 1970), bone marrow disease (Young, 1983), urinary tract complications (Casewell et al., 1977), ankylosing spondylitis (Ebringer et al., 1978), burns (Jones, Roe and Gupta, 1980; Jones, 1981) and bronchopneumonia (Darrell and Hurdle, 1964; Pennington and Menkes, 1981). The emergence of strains of $K$. aerogenes with multiple drug resistance (Thomas et al., 1977; Montgomerie, 1979; Casewell, 1982), together with its high ranking as a main cause of gram-negative bacteraemia (Montgomerie and Ota, 1980), suggests a need for an alternative approach.

Immunisation is a relatively untried method of combatting klebsiella infections. Recent research has been mainly on the protective properties of lipopolysaccharides or core-glycolipids that are common to all members of the Enterobacteriaceae (Young, Stevens and Ingram, 1975; Braude et al., 1977; Young, 1980). There have been few studies on the immunogenicity of type-specific capsular polysaccharides (Jones, 1971; Nakashima, Nagase and Kato, 1977; Riottot, Fournier and Jouin, 1981). Experimental evidence suggests that type-specific vaccines from virulent strains of gram-negative 
bacilli afford a higher degree of protection than the common protective antigens (McCabe et al., 1977; Roe and Jones, 1983; Zinner and Peter, 1983).

In this study we have immunised mice with type-specific vaccines from virulent strains, and tested the cross-protection of single and polyvalent vaccines against the 77 capsular types of $K$. aerogenes.

\section{MATERIALS AND METHODS}

Sources of bacteria. Strains of $K$. aerogenes were isolated from blood cultures of patients with burns at Birmingham Accident Hospital, and at Safdarjang Hospital, New Delhi, by methods described by Davis, Lilly and Lowbury (1969). Other hospital strains of $K$. aerogenes were kindly supplied by Dr R. Warren, Addenbrookes Hospital, Cambridge, and Dr Reeves, University Hospital, Nottingham. All strains of $K$. aerogenes were serotyped by their capsular antigens, using counter-current immunoelectrophoresis and the Quellung reaction (Palfreyman, 1978), at the Public Health Laboratory, Coventry. A representative strain of each of the 77 capsular types of $K$. aerogenes was kindly provided also from that laboratory, having been isolated originally from hospital patients in the UK. The bacteria were freeze-dried, and also maintained in subculture on nutrient agar (Oxoid) at $4^{\circ} \mathrm{C}$.

$K$. aerogenes was grown for $18 \mathrm{~h}$ at $37^{\circ} \mathrm{C}$ on $1.2 \%$ Blood Agar Base No. 2 (Oxoid), and resuspended in $10 \mathrm{ml}$ of saline to a concentration of $10^{10}$ bacteria/ml, estimated by turbidity. The bacterial suspension was added to $1.5 \mathrm{~L}$ of synthetic medium containing glucose $25 \mathrm{~g}$, ammonium lactate $\left(60 \%\right.$ syrup) $15 \mathrm{ml}, \mathrm{NaCl} 4.5 \mathrm{~g}, \mathrm{Na}_{2} \mathrm{HPO}_{4} .12 \mathrm{H}_{2} \mathrm{O} 20 \mathrm{~g}, \mathrm{KH}_{2} \mathrm{PO}_{4} 2.25 \mathrm{~g}$, Supplement A $1.5 \mathrm{ml}$, Supplement B $1.5 \mathrm{ml}$; and $\mathrm{KH}_{2} \mathrm{PO}_{4}$ crystals were added to adjust the $p \mathrm{H}$ to 7.2. Supplement A: $\mathrm{FeSO}_{4} .7 \mathrm{H}_{2} \mathrm{O} 0 \cdot 25 \mathrm{~g}, \mathrm{ZnSO}_{4} .4 \mathrm{H}_{2} \mathrm{O} 0 \cdot 25 \mathrm{~g}, \mathrm{MnSO}_{4} .4 \mathrm{H}_{2} \mathrm{O} 0 \cdot 25 \mathrm{~g}, 0 \cdot 1 \mathrm{~N} \mathrm{H}_{2} \mathrm{SO}_{4}$ $5 \mathrm{ml}, \mathrm{H}_{2} \mathrm{O} 95 \mathrm{ml}$. Supplement $\mathrm{B}: \mathrm{CaCl}_{2} .2 \mathrm{H}_{2} \mathrm{O} 1 \mathrm{~g}, \mathrm{KCl} 10 \mathrm{~g}, \mathrm{MgCl}_{2} .6 \mathrm{H}_{2} \mathrm{O} 7 \mathrm{~g}$, made up to $100 \mathrm{ml}$ with $\mathrm{H}_{2} \mathrm{O}$.

The medium (1.5 L) was pumped into a Biolab Fermenter (F.T. Biotechnology, Station Industrial Estate, Bredon, Tewkesbury, Gloucester GL20 7HH) through a $0 \cdot 2-\mu \mathrm{m}$ membrane filter (Millipore). The fermenter had automatic monitor and control facilities for $p \mathrm{H}$, temperature, antifoam, dissolved oxygen and stirring. The $p \mathrm{H}$ was set to a lower limit of $7 \cdot 15$ and upper limit of $7 \cdot 25$, control was by automatic addition of $1.0 \mathrm{~N} \mathrm{H}_{2} \mathrm{SO}_{4}$ or $1.0 \mathrm{~N} \mathrm{KOH}$ as required by $p \mathrm{H}$ sensor; the temperature of the culture was kept at $37^{\circ} \mathrm{C}$; antifoaming agent was $1.0 \%$ polypropylene glycol 2025 , and the control was set to add antifoam agent as needed; air was initially pumped into the medium at a rate of $2500 \mathrm{ml} / \mathrm{min}$ through a $0 \cdot 2-\mu \mathrm{m}$ Acro 50 hydrophobic filter (Gelman Sciences Ltd, 10 Harrowden Road, Brackmills, Northampton NN4 $0 \mathrm{~EB}$ ) until a stable state of maximum dissolved oxygen was reached; the monitor was then set to $100 \%$ dissolved oxygen, and the air supply was switched to 'control supply' which attempted to maintain this level of oxygen in the medium as conditions altered during culture (the minimum air flow during culture was $600 \mathrm{ml} / \mathrm{min}$ ); the culture was stirred constantly at $500 \mathrm{rpm}$ with four stainless steel paddles, each $2 \cdot 5 \mathrm{~cm}^{2}$.

Strains of $K$. aerogenes were grown for $48 \mathrm{~h}$ in controlled conditions; then $4.5 \mathrm{ml}$ of concentrated formaldehyde $(40 \% \mathrm{w} / \mathrm{v})$ was added to the culture and the bacteria were removed from the medium by centrifugation $\left(16000 \mathrm{~g}, 1 \mathrm{~h}, 12^{\circ} \mathrm{C}\right)$, followed by positive pressure filtration through a $0 \cdot 2-\mu \mathrm{m}$ membrane on a $142-\mathrm{mm}$ plate filter holder (Sartorius Instruments Ltd, 18 Avenue Road, Belmont, Surrey). The culture filtrate was filtered through a Nuclepore Ultrafiltration Unit with MFS membranes ( $90 \mathrm{~mm}$ diam.) type M0220A090E (V.A. Howe and Co. Ltd, 12-14 St Ann's Crescent, London SW18 2LS) which retained molecules with a mol. wt $>20000$, and reduced the volume of the retained fraction to $100 \mathrm{ml}$. Traces of medium and remaining small molecules were removed from this concentrate by diafiltration by passing $2 \times 2.5 \mathrm{~L}$ of de-ionised water through the Ultrafiltration Unit. When the retained fraction had been reduced to $400 \mathrm{ml}$ it was shell-frozen and freeze-dried. The yield of each vaccine was a minimum of $1 \mathrm{~g} / \mathrm{L}$.

For polyvalent vaccine, stock solutions of monovalent vaccines $(1.0 \mathrm{ml}$ of saline containing $1 \mathrm{mg}$ of klebsiella vaccine) were mixed and made up to $1 \mathrm{~L}$ with saline. Thus a 3-part polyvalent vaccine contained $3 \mu \mathrm{g}$ of combined klebsiella vaccines per $\mathrm{ml}$. 
Animal experiments. Female albino BKW2 mice, 22-25 g, were vaccinated and given challenge doses of live bacteria by intraperitoneal injection. They were kept at $24^{\circ} \mathrm{C}$, with food and water ad libitum; deaths were recorded up to $24 \mathrm{~h}$ after challenge or, for tests of vaccine toxicity, up to $48 \mathrm{~h}$ after vaccination.

For virulence tests, strains of $K$. aerogenes were grown on nutrient agar, and colonies of bacteria were suspended in physiological saline by shaking on a mixer. After estimation of the bacterial count by turbidity, each suspension was diluted to the required concentration. Groups of three or six mice were given $1.0-\mathrm{ml}$ inocula of serial dilutions from a maximum dose of $3 \times 10^{9}$ bacteria/ml. The highest dilution that killed a group of six mice was considered to contain a minimum lethal dose (MLD) (Jones, 1970).

Vaccines were prepared initially from strains with an MLD of $10^{8}$ bacteria or less, such as type 1 and type 20 (table I). Subsequently, however, in order to protect against all 77 capsular types, we had to include vaccines prepared from other capsular types, even though the most virulent strains that we possessed had an MLD greater than $10^{8}$ bacteria, such as types 50 and 70 .

For protection tests, groups of mice were given $1.0 \mathrm{ml}$ of single or polyvalent vaccine, and challenged 4 days later with 1 MLD of live bacteria. For those that received two doses of vaccine, the second dose was given 3 days after the first and the mice were challenged 4 days after the second dose.

For toxicity tests, groups of mice received graded doses of vaccine (table V). The six-part polyvalent vaccine was made up by adding $16 \mathrm{mg}$ of each of the six component vaccines to $10 \mathrm{ml}$ of saline to give a final concentration of combined vaccine of approximately $10 \mathrm{mg} / \mathrm{ml}$. The nine-part polyvalent vaccine was made by adding $11 \mathrm{mg}$ of each of the nine vaccines to $10 \mathrm{ml}$ of saline, giving a final concentration of combined vaccine of approximately $10 \mathrm{mg} / \mathrm{ml}$.

\section{RESULTS}

\section{Vaccine strains of $K$. aerogenes}

Of the 324 strains of $K$. aerogenes in our collection, 20 strains were classed as highly virulent, killing groups of six mice at doses of $1.0 \times 10^{8}$ bacteria/mouse or less; 24 strains were classed as avirulent, not killing mice at doses of $2.0 \times 10^{9}$ bacteria/mouse.

\section{TABLE I}

Virulence of vaccine strains of $K$. aerogenes for mice

\begin{tabular}{lc|c}
\hline \multicolumn{2}{c|}{ Strains of $K$. aerogenes } & \\
\hline Source & Capsular type & Minimum lethal dose (MLD)* \\
\hline SJH & 1 & $1 \cdot 0 \times 10^{7}$ \\
BAH & 2 & $1.0 \times 10^{7}$ \\
PHLS & 3 & $6.0 \times 10^{8}$ \\
PHLS & 15 & $6.0 \times 10^{8}$ \\
SJH & 20 & $1 \cdot 0 \times 10^{8}$ \\
PHLS & 35 & $8 \cdot 0 \times 10^{8}$ \\
SJH & 36 & $2 \cdot 0 \times 10^{8}$ \\
SJH & 44 & $1 \cdot 0 \times 10^{8}$ \\
PHLS & 50 & $1.4 \times 10^{9}$ \\
BAH & 63 & $1 \cdot 0 \times 10^{8}$ \\
PHLS & 70 & $1 \cdot 8 \times 10^{9}$ \\
SJH & 74 & $2 \cdot 8 \times 10^{8}$ \\
\hline
\end{tabular}

$\mathrm{SJH}=$ Safdarjang Hospital, New Delhi.

$\mathrm{BAH}=$ Accident Hospital, Birmingham.

PHLS $=$ Coventry area laboratory of Public Health Laboratory Service.

* Intraperitoneal injection in BKW2 mice. 
TABLE II

Cross-protection of mice after one dose of monovalent klebsiella vaccine

\begin{tabular}{|c|c|c|c|c|}
\hline \multirow{2}{*}{$\begin{array}{l}\text { Capsular types of } \\
\text { K. aerogenes present in } \\
\text { monovalent vaccines }\end{array}$} & \multicolumn{3}{|c|}{$\begin{array}{l}\text { Number of capsular types }(n=77) \\
\text { against which vaccine gave }\end{array}$} & \multirow[b]{2}{*}{$\begin{array}{l}\text { Capsular types against which } \\
\text { vaccine gave no protection }\end{array}$} \\
\hline & $\begin{array}{l}\text { complete* } \\
\text { protection }\end{array}$ & $\begin{array}{c}\text { partial } \\
\text { protection }\end{array}$ & $\begin{array}{c}\text { no† } \\
\text { protection }\end{array}$ & \\
\hline 1 & 43 & 13 & 21 & \multirow{7}{*}{$\begin{array}{l}2152024253235444648495255 \\
5758596062636469 \\
3561520232427354042444749 \\
50636574 \\
1251011141720242931353645 \\
46495563686971727374 \\
123458121316181920222426 \\
32353640444657586971737475 \\
234624263135404144454950 \\
63686970717374 \\
12101417202224253059646768 \\
69717374 \\
122035505859636465\end{array}$} \\
\hline 2 & 42 & 17 & 18 & \\
\hline 3 & 34 & 19 & 24 & \\
\hline 15 & 30 & 19 & 28 & \\
\hline 20 & 38 & 18 & 21 & \\
\hline 35 & 42 & 17 & 18 & \\
\hline 44 & 46 & 21 & 10 & \\
\hline
\end{tabular}

The 12 vaccine strains (table I) were derived mainly from highly virulent bacteria, e.g., types $1,2,20,44,63$, and only three (types 35,50 and 70 ) were from relatively avirulent strains.

\section{Protection by single dose of monovalent vaccine}

Seven monovalent vaccines each protected mice against different ranges of 30-46 types of $K$. aerogenes (table II). The groups of vaccinated mice were challenged with 77 types, at a time when the maximum cross-protective response occurs, i.e., 4 days after a single dose of vaccine (Roe and Jones, 1984). Vaccine 44 induced protection against the largest number of types (46), and failed to protect all the mice in a group against only 10 types. Each monovalent vaccine protected against the type from which it was made and also against a random set of other types, and there seemed to be no particular strain or set of strains (table II) against which the vaccines were incapable of inducing protection.

\section{Protection by single dose of polyvalent vaccine}

Ten polyvalent vaccines, containing 2-12 components, all protected mice against more types than did the individual components (table III). The 7-12-part polyvalent vaccines protected against more types than the two-part vaccines. Also, more groups of mice showed partial protection (2-5 survivors out of 6 challenged), with a consequent reduction in the number of groups that received no protection. One polyvalent vaccine $(1 / 2 / 3 / 15 / 20 / 35 / 44)$ induced full or partial protection against all but five of the 77 types.

Single injections of two-part vaccines resulted in only small gains in protection compared with monovalent vaccine. Both of the two-part vaccines $(1 / 44$ and $2 / 20)$ 
TABLE III

Cross-protection of mice after one dose of polyvalent klebsiella vaccine

\begin{tabular}{|c|c|c|c|c|}
\hline \multirow[b]{2}{*}{$\begin{array}{l}\text { Capsular types of } K \text {. aerogenes } \\
\text { present in polyvalent vaccines }\end{array}$} & \multicolumn{3}{|c|}{$\begin{array}{l}\text { Number capsular types }(\mathrm{n}=77) \\
\text { against which vaccine gave }\end{array}$} & \multirow[b]{2}{*}{$\begin{array}{l}\text { Capsular types against which } \\
\text { vaccine gave no protection }\end{array}$} \\
\hline & $\begin{array}{l}\text { complete* } \\
\text { protection }\end{array}$ & $\begin{array}{c}\text { partial } \\
\text { protection }\end{array}$ & $\begin{array}{c}\text { not } \\
\text { protection }\end{array}$ & \\
\hline 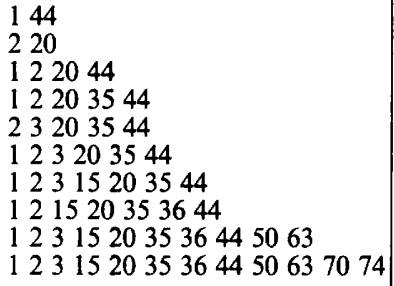 & $\begin{array}{l}48 \\
46 \\
51 \\
49 \\
58 \\
55 \\
49 \\
53 \\
53 \\
61\end{array}$ & $\begin{array}{r}16 \\
23 \\
15 \\
18 \\
7 \\
12 \\
23 \\
18 \\
17 \\
10\end{array}$ & $\begin{array}{r}13 \\
8 \\
11 \\
10 \\
12 \\
10 \\
5 \\
6 \\
7\end{array}$ & $\begin{array}{l}2152023323546485059636973 \\
1535505265707174 \\
1115253235414550607374 \\
24615161736606374 \\
1211202325324669717274 \\
12152729556367697374 \\
3556737475 \\
43663707476 \\
143663707476 \\
23550526970\end{array}$ \\
\hline
\end{tabular}

$* 6 / 6$ mice protected.

$\dagger 0 / 6$ protected.

failed to protect mice against some types of $K$. aerogenes for which the component monovalent vaccines had given protection; but, conversely, they induced protection against types for which neither of the individual component vaccines had protected.

\section{Protection by two doses of vaccine}

Two injections of monovalent vaccines 1 and 2 (table IV) gave protection against an almost identical range of types to that protected by one injection (table II); also the protection induced by one or two injections of two-part vaccines $(1 / 44,2 / 20)$ was nearly identical.

However, with vaccines containing more than seven components, two injections induced protection against more types than one injection. For example, vaccine $1 / 2 / 3 / 15 / 20 / 35 / 36 / 44 / 50 / 63 / 70 / 74$ protected completely against 61 types after one dose (table III) and against 71 types after two doses (table IV). Indeed, two doses of this vaccine gave some degree of protection against all 77 types.

When each of the two doses of polyvalent vaccine $1 / 2 / 3 / 15 / 20 / 35 / 36 / 44 / 63$ was increased 10 -fold there was a substantial broadening of the protective response (table IV): the higher dose ( $90 \mu \mathrm{g} / \mathrm{mouse})$, gave complete protection against 73 types, whereas the lower dose $(9 \mu \mathrm{g})$ protected against only 46 types.

\section{Toxicity of vaccine}

Monovalent vaccines 2, 3 and 44 were the least toxic, failing to kill mice with 5000 immunising doses (table V). The two most toxic vaccines were 36 and 50, which killed $50 \%$ of the mice with $1250 \mathrm{immunising}$ doses. The polyvalent vaccines were found to be less toxic than the most toxic of the individual components: a 6-part polyvalent vaccine killed only $50 \%$ of mice with 5000 immunising doses, and a 9-part vaccine killed no mice with 1250 immunising doses. 


\section{TABLE IV}

\section{Cross-protection of mice after two doses of monovalent or polyvalent klebsiella vaccine*}

\begin{tabular}{|c|c|c|c|c|}
\hline \multirow{2}{*}{$\begin{array}{l}\text { Capsular types of } \\
K \text {. aerogenes present in } \\
\text { monovalent or } \\
\text { polyvalent vaccine }\end{array}$} & \multicolumn{3}{|c|}{$\begin{array}{l}\text { Number of capsular types }(n=77) \\
\text { against which vaccine gave }\end{array}$} & \multirow[b]{2}{*}{$\begin{array}{l}\text { Capsular types against which } \\
\text { vaccine gave no protection }\end{array}$} \\
\hline & $\begin{array}{l}\text { complete } \dagger \\
\text { protection }\end{array}$ & $\begin{array}{c}\text { partial } \\
\text { protection }\end{array}$ & $\begin{array}{c}\text { noł } \\
\text { protection }\end{array}$ & \\
\hline 1 & 43 & 13 & 21 & $\begin{array}{r}21520242532 \quad 3544 \quad 464849 \\
52555758 \quad 5960 \quad 62636469\end{array}$ \\
\hline 2 & 41 & 18 & 18 & $\begin{array}{l}356152023242735404244 \\
474950636574\end{array}$ \\
\hline 20 & 38 & 18 & 21 & $\begin{array}{c}2346242631354041444549 \\
50636869707173.74\end{array}$ \\
\hline $\begin{array}{l}44 \\
144\end{array}$ & $\begin{array}{l}44 \\
46\end{array}$ & $\begin{array}{l}24 \\
17\end{array}$ & $\begin{array}{r}9 \\
14\end{array}$ & $\begin{array}{l}1235505859636465 \\
212202332354648515759 \\
636974\end{array}$ \\
\hline $\begin{array}{l}220 \\
122044\end{array}$ & $\begin{array}{l}46 \\
51\end{array}$ & $\begin{array}{l}23 \\
13\end{array}$ & $\begin{array}{r}8 \\
13\end{array}$ & $\begin{array}{l}1535505265707174 \\
1115202532354145506070 \\
7374\end{array}$ \\
\hline $\begin{array}{l}12315203544506374 \\
12215203544637074 \\
1221520353644637074 \\
122315203536\end{array}$ & $\begin{array}{l}54 \\
56 \\
64\end{array}$ & $\begin{array}{r}20 \\
13 \\
9\end{array}$ & $\begin{array}{l}3 \\
8 \\
4\end{array}$ & $\begin{array}{l}577174 \\
23495068707374 \\
5152935\end{array}$ \\
\hline $\begin{array}{r}4450637074 \\
1231520 \\
35364463\end{array} \quad\left\{\begin{array}{r}90 \mu \mathrm{g} \\
9 \mu \mathrm{g}\end{array}\right.$ & $\begin{array}{l}71 \\
73 \\
46\end{array}$ & $\begin{array}{r}6 \\
2 \\
19\end{array}$ & $\begin{array}{r}0 \\
2 \\
12\end{array}$ & $\begin{array}{l}5865 \\
1316171819273558697173\end{array}$ \\
\hline
\end{tabular}

* Mice received a second dose of the same vaccine, 3 days after the first, and were challenged 4 days later. $\uparrow 6 / 6$ mice protected.

$\ddagger 0 / 6$ protected.

\section{TABLE V}

Toxicity of monovalent and polyvalent klebsiella vaccines

\begin{tabular}{|c|c|c|c|c|c|c|c|}
\hline \multirow{2}{*}{$\begin{array}{l}\text { Capsular types of } K \text {. aerogenes } \\
\text { present in vaccines }\end{array}$} & \multicolumn{7}{|c|}{$\begin{array}{l}\text { Number of deaths out of } 6 \\
\text { mice given the } \\
\text { following doses of vaccine }\end{array}$} \\
\hline & $10 \mathrm{mg}$ & $5 \mathrm{mg}$ & $2.5 \mathrm{mg}$ & $1.25 \mathrm{mg}$ & $100 \mu \mathrm{g}$ & $10 \mu \mathrm{g}$ & $1 \mu \mathrm{g}^{*}$ \\
\hline $\begin{array}{l}1 \\
2 \\
3 \\
15 \\
20 \\
35 \\
36 \\
44 \\
50 \\
63\end{array}$ & $\begin{array}{l}6 \\
6 \\
6 \\
6 \\
6 \\
6 \\
6 \\
6 \\
6 \\
6\end{array}$ & $\begin{array}{l}6 \\
0 \\
0 \\
6 \\
6 \\
6 \\
6 \\
0 \\
6 \\
3\end{array}$ & $\begin{array}{l}0 \\
0 \\
0 \\
6 \\
6 \\
0 \\
6 \\
0 \\
6 \\
0\end{array}$ & $\begin{array}{l}0 \\
0 \\
0 \\
0 \\
0 \\
0 \\
3 \\
0 \\
3 \\
0\end{array}$ & $\begin{array}{l}0 \\
0 \\
0 \\
0 \\
0 \\
0 \\
0 \\
0 \\
0 \\
0\end{array}$ & $\begin{array}{l}0 \\
0 \\
0 \\
0 \\
0 \\
0 \\
0 \\
0 \\
0 \\
0\end{array}$ & $\begin{array}{l}0 \\
0 \\
0 \\
0 \\
0 \\
0 \\
0 \\
0 \\
0 \\
0\end{array}$ \\
\hline $\begin{array}{lllll}1 & 23203544 \\
1 & 233152035364463\end{array}$ & $\begin{array}{l}6 \\
6\end{array}$ & $\begin{array}{l}3 \\
6\end{array}$ & $\begin{array}{l}0 \\
6\end{array}$ & $\begin{array}{l}0 \\
0\end{array}$ & $\begin{array}{l}0 \\
0\end{array}$ & $\begin{array}{l}0 \\
0\end{array}$ & $\begin{array}{l}0 \\
0\end{array}$ \\
\hline
\end{tabular}

* $1 \mu \mathrm{g}$ was the dose used for immunisation (table II). 


\section{Discussion}

Most $K$. aerogenes infections occur in patients who are already weakened by disease (Young, 1982) and in whom contemporary chemotherapy seems ineffective (Thomas et al., 1977). The experiments with polyvalent klebsiella vaccines are a promising step towards an immunological approach to such infections. In previous experiments (Roe and Jones, in press) mice were found to be protected against lethal infection as early as 4 days after a single injection of a monovalent vaccine. The present experiments have shown that polyvalent vaccines can induce a similar early protection against almost all 77 capsular types. Broad spectrum early protective responses are not unique to klebisella vaccines; they were found in mice immunised with pseudomonas vaccines (Jones, 1971) and in severely burned patients whose lives were saved by early protective responses induced by a polyvalent pseudomonas vaccine (Roe and Jones, 1983).

Each klebsiella vaccine induced protection against 30 or more capsular types of $K$. aerogenes and the vaccines that induced the widest protective cover were usually derived from mouse-virulent strains. Thus if culture filtrates were to be used for making a polyvalent vaccine against all 77 types, it would be advantageous to seek virulent strains for vaccine preparation.

The pooling of monovalent vaccines produced some confusing protective responses in the mice, as protection against a challenge strain could be either lost or gained as a result of pooling the vaccines. One explanation for this observation is that each monovalent vaccine contains several immunogenic constituents, and when combined with other vaccines the amounts of the minor constituents in the polyvalent vaccine are above or below a level capable of initiating an immune response. The practical outcome was that there seemed no way of predicting what protective response might be produced after pooling. Thus the polyvalent vaccines were made on a 'trial and error' basis, adding extra monovalent vaccines that gave protection against capsular types for which the initial polyvalent vaccine failed to protect, in the hope that protection against the remaining types might be achieved.

The protective response was enhanced, and became more predictable and stable, by increase in the number of doses and in the size of each dose; some of the protection lost on combining monovalent vaccines re-appeared. We are investigating this further.

The medium used for vaccine production was intended to enhance the yield of capsular polysaccharide; it had a high sugar:nitrogen ratio (Duguid and Wilkinson, 1953; Wilkinson, Duguid and Edmunds, 1954). After $24 \mathrm{~h}$, growth was limited by nitrogen deficiency, and the excess sugar became available during the next $24 \mathrm{~h}$ for synthesis of capsular polysaccharide. We attempted to extract the vaccines from the culture filtrates, undenatured and free from medium and toxic contaminants; this was achieved by culturing in a synthetic dialysable medium and using low stress physical methods for extraction (diafiltration and centrifugation). The resulting vaccines were water-soluble and caused no harmful effects in mice at the immunising doses: the level of lethal toxicity was $>1000$ protective doses of monovalent vaccine.

We gratefully acknowledge the technical assistance of R. E. Dyster in the preparation of the vaccines. 


\section{REFERENCES}

Braude A I, Ziegler E J, Douglas H, McCutchan J A 1977 Antibody to cell wall glycolipid of gram-negative bacteria: induction of immunity to bacteremia and endotoxemia. Journal of Infectious Diseases 136 Supp: 167-173.

Bryan C S, Reynolds K L, Brenner E R 1983 Analysis of 1,186 episodes of gram-negative bacteremia in non-university hospitals: the effects of antimicrobial therapy. Reviews of Infectious Diseases 5:629-638.

Casewell M W 1982 The role of multiply resistant coliforms in hospital-acquired infection. In: Reeves D S, Geddes A M (eds) Recent advances in infection, vol 2. Churchill Livingstone, Edinburgh, p31.

Casewell M W, Dalton M T, Webster M, Phillips I 1977 Gentamicin-resistant Klebsiella aerogenes in a urological ward. Lancet 2: 444-446.

Darrell J H, Hurdle A D F 1964 Identification and clinical significance of Klebsiella species in chest infections. Journal of Clinical Pathology 17:617-621.

Davis B, Lilly H A, Lowbury E J L 1969 Gram-negative bacilli in burns. Journal of Clinical Pathology 22:634-640.

Duguid J P, Wilkinson J F 1953 The influence of cultural conditions on polysaccharide production by Aerobacter aerogenes. Journal of General Microbiology 9:174-189.

Ebringer R W, Cawdell D R, Cowling P, Ebringer A 1978 Sequential studies in ankylosing spondylitis: association of Klebsiella pneumoniae with active disease. Annals Rheumatic Diseases 37: 146-151.

Foster W D, Bragg J 1962 Biochemical classification of Klebsiella correlated with the severity of the associated disease. Journal of Clinical Pathology 15:478-481.

Jones R J 1970 Passive immunisation against gram-negative bacilli in burns. British Journal of Experimental Pathology 51:53-58.

Jones R J 1971 Early protection by vaccines in burns. British Journal of Experimental Pathology 52:100-109.

Jones R J 1981 Vaccines and antisera against gram-negative bacilli. Journal of Hospital Infection 2:105-111.

Jones R J, Roe E A, Gupta J L 1980 Controlled trial of pseudomonas immunoglobulin and vaccine in burn patients. Lancet 2:1263-1265.

McCabe W R, Bruins S C, Craven D E, Johns M 1977 Cross-reactive antigens: Their potential for immunization induced immunity to gram-negative bacteria. Journal of Infectious Diseases 136 Supp:161-166.

McHenry M C, Hawk W A 1974 Bacteraemia caused by gram-negative bacilli. Medical Clinics of North America 58:623-638.

Montgomerie J Z 1979 Epidemiology of Klebsiella and hospital-associated infections. Reviews of Infectious Diseases 1:736-753.

Montgomerie J Z, Doak P B, Taylor D E M, North J D K, Martin W J 1970 Klebsiella in faecal flora of renal transplant patients. Lancet 2:787-792.

Montgomerie J Z, Ota J K 1980 Klebsiella bacteremia. Archives of Internal Medicine 140:525-527.

Nakashima I, Nagase F, Kato N 1977 Adjuvant action of capsular polysaccharide of Klebsiella pneumoniae on antibody response. VI. Site of its action. Zeitschrift für Immunitatsforschung: Immunobiology 153: 204-216.

Palfreyman J M 1978 Klebsiella serotyping by counter-current immunoelectrophoresis. Journal of Hygiene $81: 219-226$.

Pennington J E, Menkes E 1981 Type-specific cross-protective vaccination for gram-negative bacterial pneumonia. Journal of Infectious Diseases 144:599-603.

Price D J E, Sleigh J D 1970 Control of infection due to Klebsiella aerogenes in a neurosurgical unit by withdrawal of all antibiotics. Lancet 2: 1213-1215.

Rennie R P, Duncan I B 1974 Combined biochemical and serological typing of clinical isolates of Klebsiella. Applied Microbiology 28:534-539.

Riottot M M, Fournier J M, Jouin H 1981 Direct evidence for the involvement of capsular polysaccharide in the immunoprotective activity of Klebsiella pneumoniae ribosomal preparations. Infection and Immunity $31: 71-77$. 
Roe E A, Jones R J 1983 Immunization of burned patients against Pseudomonas aeruginosa infection at Safdarjang Hospital, New Delhi. Reviews of Infectious Diseases 5 Suppl:922-930.

Roe E A, Jones R J Vaccination against Klebsiella aerogenes. Journal of Hygiene (in press).

Steinhauer B W, Eickhoff T C, Kislak J W, Finland M 1966 The Klebsiella-Enterobacter-Serratia division: Clinical and epidemiological characteristics. Annals of Internal Medicine 65:1180-1194.

Thomas F E, Jackson R T, Melly M A, Alford R H 1977 Sequential hospital-wide outbreaks of resistant serratia and klebsiella infections. Archives of Internal Medicine 137:581-584.

Umsawasdi T, Middleman E A, Luna M, Bodey G P 1973 Klebsiella bacteremia in cancer patients. American Journal of Medical Sciences 265:473-482.

Wardle N 1979 Bacteraemic and endotoxic shock. British Journal of Hospital Medicine $21: 223-231$.

Wilkinson J F, Duguid J P, Edmunds P N 1954 The distribution of polysaccharide production in Aerobacter and Escherichia strains and its relation to antigenic character. Journal of General Microbiology 11:59-72.

Young L S 1980 Immunoprophylaxis and immunotherapy of infection in the compromised host. In: Verhoef J, Peterson P K, Quie P G (eds) Infections in the immunocompromised host, Elsevier, Amsterdam, p 283.

Young L S 1983 Infectious complications in bone marrow transplant recipients. In: Easmon CSF, Gaya $\mathrm{H}$ (eds) Second international symposium on infections in the immunocompromised host, Academic Press, London, p 27.

Young L S, Stevens P, Ingram J 1975 Functional role of antibody against "core" glycolipid of Enterobacteriaceae. Journal of Clinical Investigation 56:850-861.

Young L S, Martin W J, Meyer R D, Weinstein R J, Anderson E T 1977 Gram-negative rod bacteraemia: microbiologic, immunological and therapeutic considerations. Annals of Internal Medicine 86:456-471.

Young S E J 1982 Bacteraemia 1975-1980: A survey of cases reported to PHLS Communicable Disease Surveillance Centre. Journal of Infection 5:19-26.

Ziegler E J, McCutchan J A, Fierer J, Glauser M P, Sadoff J C, Douglas H, Braude A I 1982 Treatment of gram-negative bacteraemia and shock with human antiserum to a mutant Escherichia coli. The New England Journal of Medicine 307:1225-1230.

Zinner S H, Peter G 1983 The potential role of cell wall core-glycolipids in the immunoprophylaxis and therapy of gram-negative rod bacteraemia. In: Easmon C S F, Jeljaszewicz J (eds) Medical Microbiology vol 2, Immunisation against bacterial disease, Academic Press, London, $\mathrm{p} 71$. 